\title{
EKSPLORASI TEKNIK SHIBORI DALAM PENGEMBANGAN DESAIN MOTIF TRADISIONAL INDONESIA PADA PERMUKAAN KAIN SANDANG
}

\author{
SHIBORI TECHNIQUE EXPLORATION IN DEVELOPING INDONESIAN \\ TRADITIONAL MOTIF DESIGN IN CLOTHING FABRIC SURFACE
}

\author{
Dermawati Suantara, Endah Oktaviani, Yusniar Siregar
}

Balai Besar Tekstil, Jalan Jenderal Ahmad Yani No. 390 Bandung

E-mail: texirdti@bdg.centrin.net.id

Tanggal diterima: 22 Agustus 2017, direvisi: 9 Januari 2018, disetujui terbit: 11 Januari 2018

\begin{abstract}
ABSTRAK
Penelitian ini bertujuan untuk membuat kain sandang bermotif tradisional Indonesia hasil dari eksplorasi teknik Shibori yang berasal dari Jepang, namun di Indonesia lebih dikenal dengan nama ikat celup. Hasil pengukuran persepsi visual terhadap motif shibori $(n=50)$ menunjukkan bahwa meskipun motif Shibori 3 merupakan motif yang paling unik (skor rata-rata $=.56$ ), namun motif Shibori 1 merupakan motif yang paling disukai responden (skor rata-rata $=.26$ ) serta memiliki tingkat minat beli yang tertinggi (skor rata-rata $=.08$ ). Preferensi responden terbangun dari rata-rata skor persepsi elemen visual Shibori 1 yang mencakup: (1) tingkat kerumitan motif (skor rata-rata=.32); (2) komposisi dinamis (skor rata-rata=.62); dan (3) kesan pembawaan yang elegan (skor ratarata=.66). Hasil dari eksplorasi teknik Shibori yang lebih beragam ini diharapkan dapat memberikan wawasan pada IKM celup ikat bahwa beragam motif tradisional Indonesia dapat diaplikasikan dan dikembangkan pada kain ikat celup yang selama ini hanya menampilkan motif-motif yang sederhana yang dihasilkan dari ikat celup biasa.
\end{abstract}

Kata kunci : kain sandang, Shibori, ikat celup, motif, tradisional

\begin{abstract}
This research is aimed to make Indonesian traditional patterned clothing fabric from the exploration techniques of Shibori that derived from Japan, that in Indonesia is knowed as tie dye. The result of visual perception measurement towards shibori motif $(n=50)$ show that Shibori 3 motif is the most unique motif (mean score $=.56$ ), however Shibori 1 motif is the most likeable motif by respondents (mean score=.26) and have the highest preference of buying (mean score=.08). Respondent's preference is built from mean score of visual elements of Shibori motif 1 inculding: (1) motif complication rate (mean score=.32); (2) dynamic composition (mean score=.62); and (3) elegant image (mean score=.66). The results from the more diverse exploration of Shibori techniques are expected to provide insights on the tie dye from small and medium industry that diverse Indonesian traditional motifs can be applied and developed on tie dye fabric which has only been showing simple motifs produced from ordinary binding.
\end{abstract}

Key words: clothing fabric, Shibori, tie dye, motif, traditional 


\section{PENDAHULUAN}

Pencelupan berkembang melalui berbagai kebudayaan di dunia, dan dipraktekan sebagai salah satu seni khusus seperti di negara Cina, Jepang, Amerika Latin dan Afrika. Shibori adalah salah satu cara pencelupan tekstil di Jepang sejak abad ke 8. Shibori merupakan teknik pencelupan kain yang meliputi jahitan, ikatan, lilitan, dijepit dan dibungkus. Teknik dasar Shibori adalah menggambar diatas kain, dan pengikatan simpul dengan ketat menggunakan benang. Setelah itu, kain dicelup dengan satu atau banyak warna. Kain dicelup beberapa kali berdasarkan pada warna yang digunakan dan motif dibuat.

Shibori berasal dari Jepang, kerajinan konvensional ini dipraktekan di seluruh dunia. Tradisi Shibori telah ada di Timur Tengah dan juga di belahan benua India. Sekarang diikuti secara aktif di Cina Selatan, Afrika Barat, Indonesia, bangsa Himalaya, dan di daerah barat India. ${ }^{1}$ Shibori berasal dari kata benda Jepang akar Shiboru, "untuk memeras, diremas, ditekan". Terjemahan yang paling mendekati adalah "dibentuk-tahan celup". Teknik Shibori memberikan bentuk tiga dimensi dengan teknik melipat, meremas, jahitan, anyaman, atau mencabut dan memutar.

Di awal tahun 1990 an, beberapa produsen generasi muda dan pengrajin Shibori dihadapkan pada kenyataan bahwa teknik yang berusia berabad-abad, sumber mata pencaharian mereka, tidak akan bertahan di milenium berikutnya. Sehingga mereka memutuskan untuk melestarikannya dengan mempromosikan tekstil Shibori kedalam dan luar Jepang. Hal ini menyebabkan diadakannya First International Shibory Symposium di Nagoya pada tahun 1992 dan berikutnya dibentuk World Shibori Network (Jaringan Shibori Dunia), yang dimulai dari pengembangan kolaborasi dengan perancang busana.

Seperti ekspresi dari bentuk-bentuk tekstil lain, Shibori akan bertahan dan bahkan berkembang selama para seniman terus mencari kemungkinan kreatif dalam menggabungkan teknologi tinggi dengan pekerjaan tangan (handwork). Pada abad ke 21, kita membutuhkan teknologi untuk melayani kebutuhan manusia, menemukan berbagai cara untuk melestarikan dan mengisi sumber daya yang terbatas dan menggunakannya lebih bijak dan efisien. ${ }^{2,3}$

Shibori menjadi penggunaan populer untuk mewakili keseluruhan teknik dan gaya rentang yang tersebar di seluruh dunia, karena tidak ada nama Inggrisnya yang setara. Bahkan kebanyakan bahasa tidak mempunyai istilah yang mencakup semua jenis teknik Shibori, juga tidak ada terminologi bahasa Inggris untuk metode individu yang seringkali disalah artikan sebagai "ikat dan celup". Tiga hal untuk memisahkan metoda Shibori kedalam penggunaan bahasa internasional; Plangi, adalah bahasa Melayu-Indonesia untuk proses menyatukan dan mengikat kain; bandhani, istilah India untuk prosees yang sama; dan tritik, bahasa Melayu-Indonesia untuk jahitrintang. Bagaimanapun, tiga istilah ini mewakili hanya dua dari teknik besar Shibori.

Di Indonesia sendiri, Shibori biasa disebut jumputan walaupun secara teknik masih dilakukan dengan cara-cara yang cukup sederhana. Berbeda dengan kain tekstil yang dijual di toko kain pada umumnya, Shibori memiliki keistimewaan tersendiri berupa unsur warna dan motif yang tidak terduga dari proses pencelupan.

Ikat celup telah digunakan di banyak pulau di Nusantara, antara lain Sumatera, Jawa, Bali, Sulawesi dan sebagian pulau Kalimantan pada bahan yang biasanya dipakai adalah dimulai dari kapas hingga sutera Shantung Cina yang halus. Masyarakat Palembang menyebut kain tie- dye dengan istilah kain pelangi, masyarakat Banjarmasin menyebutnya dengan nama Sasirangan, sedangkan masyarakat Jawa menggunakan istilah tritik untuk mendefinisikan kain yang sama. Di Indonesia sendiri, istilah tie-dye jarang digunakan, karena sebagian masyarakat lebih sering menyebutnya dengan nama kain jumputan. ${ }^{4}$

Bentuk motif tradisional yang biasa dibuat di kain Pelangi antara lain bentuk belah ketupat, kulit kerang, dan kotak. Motif Tritik pada umumnya linear, bentuk motif menyerupai tetesan air mengelilingi satu garis. Pada pakaian jumputan dari Sumatera, yang biasa dikenal dengan kain Pelangi Palembang. Kain Pelangi Palembang ini dibentuk oleh motif-motif paisley India, bintang, bujur sangkar, api atau tumpal, dan belah ketupat. Jumputan Bali dan Jawa lebih primitif dan dramatis, pola motif lebih ke pola linier, bentuk motif pada umumnya motif zig-zag, dan belah ketupat. Kain Sasirangan merupakan kain tradisional yang pada awalnya tidak digunakan secara bebas karena dianggap sebagai obat untuk menyembuhkan berbagai macam penyakit. Disamping corak dan warna tradisional yang sudah baku, saat ini terlihat 
Eksplorasi teknik shibori dalam pengembangan desain motif tradisional Indonesia pada permukaan kain sandang (Dermawati Suantara, dkk)

pula corak yang baku dengan permainan nuansa yang lebih beragam, mengikuti selera yang berlaku pada saat ini.

Lebih lanjut Pujiati (2005) menuliskan, sifat-sifat bahan (kain) yang kurang padat, baik dari konstruksi anyaman maupun dari twist benang yang rendah akan mudah menyerap zat warna, sehingga motif/ desain yang dihasilkan akan kurang baik (tidak jelas). ${ }^{\mathbf{5 , 6}}$

Menurut asalnya, zat pewarna dapat digolongkan dalam dua macam yaitu: zat pewarna alam dan zat pewarna sintetis. ${ }^{\mathbf{7} 8}$ Zat pewarna sintetis adalah zat pewarna yang diperoleh dari hasil campuran unsur- unsur kimia, proses pembuatannya melalui perlakuan pemberian asam sulfat atau asam nitrat. Asamasam tersebut sering kali terkontaminasi oleh arsen atau logam yang bersifat racun. Pewarna sintetis secara cepat menggantikan peran dari pewarna alami sebagai bahan pewarna. Hal ini disebabkan karena biaya produksinya yang lebih ekonomis, varian warna yang lebih banyak dan praktis dalam penggunaan. Pewarna sintetis diklasifikasikan berdasarkan cara penggunaan pada proses pewarnaan. Beberapa zat pewarna sintetis yang dapat digunakan untuk mewarnai bahan tekstil antara lain naphtol, indigosol, rapid. Dalam penggunaannya, pewarna sintetis lebih praktis karena prosesnya hanya melarutkan pewarna dengan air hangat dan air dingin, tanpa harus mengolahnya menjadi ekstrak terlebih dahulu. Waktu yang dibutuhkanpun relatif sebentar. ${ }^{9}$

Sampai saat ini teknologi proses celup ikat di IKM-IKM Indonesia masih terbatas dengan lilit benang belum variatif, motif-motif yang dihasilkan hanya motif kotak -kotak dan bulat- bulat, padahal dengan inovasi teknologi proses jumputan akan menghasilkan berbagai macam model atau motif celup ikat yang lebih variatif dan lebih beraneka macam sehingga desain produk akan berkembang. Untuk menghadapi era globalisasi dituntut produk yang inovatif dan kreatifsehingga mampu bersaing dipasar global atau pasar Luar Negeri. ${ }^{10,11}$ Sedangkan pada Shibori, motif yang dihasilkan lebih bervariasi dan lebih terkesan rumit.

Berdasarkan hal tersebut, maka dilakukan kegiatan eksplorasi teknik Shibori ini dalam pembuatan motif-motif tradisional Indonesia yang belum pernah dibuat menggunakan teknik Shibori. Adapun beberapa teknik yang digunakan pada penelitian ini antara lain teknik Kanoko Shibori, Nui Shibori, Kumo Shibori dan Suji
Shibori yang cukup mewakili dan memungkinkan untuk membuat beberapa motif tradisional Indonesia.

Industri Kecil dan Menengah (IKM) memiliki peran yang strategis dalam perekonomian nasional, terutama dalam penyerapan tenaga kerja, peningkatan pendapatan masyarakat serta menumbuhkan aktivitas perekonomian di daerah. Pengembangan IKM merupakan bagian integral dari upaya pengembangan ekonomi kerakyatan dan pengentasan kemiskinan. Pengembangan dan pemberdayaan IKM merupakan langkah strategis, karena potensinya yang besar dalam menggerakan perekonomian dan kesejahteraan masyarakat. ${ }^{\mathbf{1 2}}$

\section{METODE}

Diagram alir eksplorasi yang dilakukan ditunjukkan pada Gambar 1.

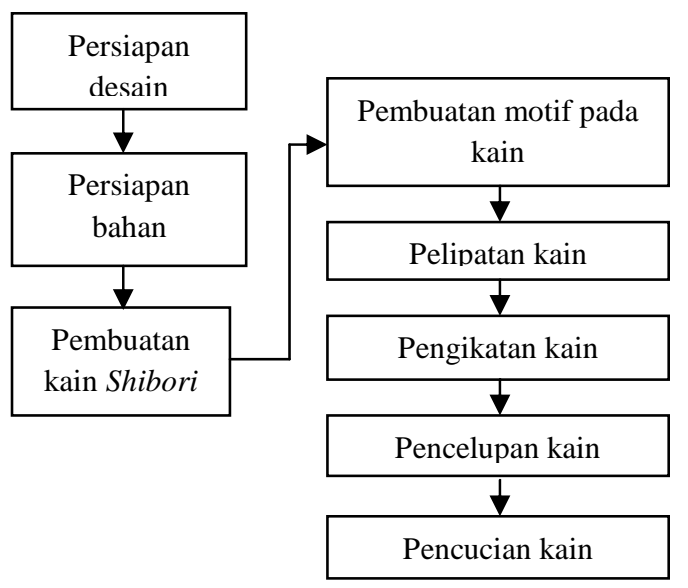

Gambar 1. Alur penelitian

Uji coba dilakukan dengan cara eksplorasi teknik shibori dari 3 motif tradisional Indonesia. Hasil uji coba diamati secara visual dan dianalisa hasilnya. Hasil percobaan diuji kemiripan dan kesukaan yang melibatkan 15 responden desainer dan 50 responden non desainer untuk mengetahui tingkat penerimaan masyarakat terhadap produk ini.

\section{Bahan dan Peralatan}

Bahan baku dalam eksplorasi ini adalah kain kapas, zat warna reaktif panas, dan zat pembantu sodium sulfat dan matexi. Peralatan yang digunakan meliputi jarum jahit, gunting, karet, benang nylon, tali rafia, tiang atau tongkat, kompor, panci dan ember. 


\section{Jenis Bahan Baku Kain}

Kain sebagai bahan baku utama produk Shibori, pada umumnya berupa mori dengan berbagai kualitas. Adapun jenis-jenis bahan baku kain adalah sebagai berikut:

1. Kain katun: mori Primissima, mori Prima, mori biru, Kain Blaco, mori Voiliissima, Kain Bercolin, Kain Paris.

2. Kain Sutra: Kain Sutra Lokal Sulawesi Selatan, kain sutra lokal Garut, kain sutra impor T 54, kain sutra impor T 56, kain sutra impor Crinkle, kain sutra impor Sifon, kain sutra organdi, kain sutra Crep.

3. Kain sintetis: kain Polyester. ${ }^{13}$

\section{Proses Persiapan Desain}

Tahap awal dalam perencanaan dan pembuatan desain adalah pemilihan beberapa motif tradisional Indonesia yang dapat dibuat dalam proses Shibori. Motif yang telah dipilih digambar kembali diatas kain, yang kemudian akan diproses menggunakan teknik Shibori.

Dalam proses persiapan, kain yang akan digunakan adalah kain kapas dengan ukuran 30 x $30 \mathrm{~cm}$, karena percobaan eksplorasi ini merupakan prototipe pengembangan teknik Shibori.

\section{Cara}

Proses awal dalam pembuatan kain shibori ini adalah persiapan desain motif tradisional yang akan diambil sebagai bahan eksplorasi teknik ini. Desain motif ditracing menggunakan komputer untuk memudahkan dalam penggambaran diatas kain. Setelah desain motif selesai dibuat, dilakukan persiapan bahan, seperti kain, benang, zat warna dan lain-lain yang diperlukan didalam melakukan proses pembuatan kain Shibori.

\section{Proses Pembuatan Kain Shibori}

Beberapa teknik Shibori yang akan digunakan antara lain:

a) Teknik Kanoko Shibori, teknik ini disebut juga celup ikat. Beberapa bagian kain diikat menggunakan benang atau karet untuk mendapatkan motif yang diinginkan. Motif ini digunakan untuk membuat motif segi empat.

b) Teknik Nui Shibori, Pada proses ini menggunakan running stitch sederhana dan kain ditarik bersamaan agar menjadi ketat, selanjutnya di ikat dan dicelup. Proses ini merupakan proses yang membutuhkan banyak waktu dan digunakan untuk membuat motif-motif tradisional yang rumit.

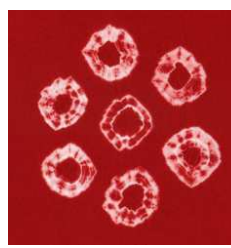

(a)

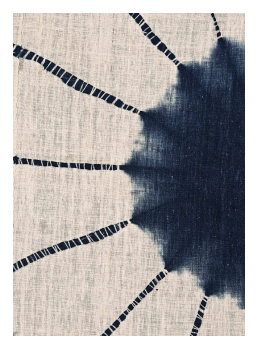

(c)

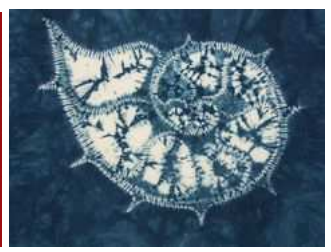

(b)

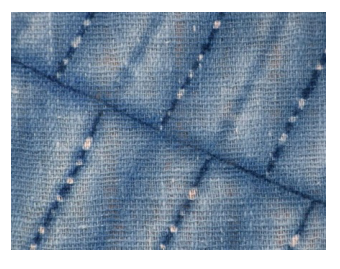

(d)
Gambar 2. (a) Kanoko Shibori, (b) Nui Shibori, (c) Kumo Shibori, (d) Suji Shibori

c) Teknik Kumo Shibori, pada teknik ini kain dilipat dan diikat sangat berdekatan dan digunakan untuk membuat motifmotif berbentuk lingkaran.

d) Teknik Suji Shibori, pada teknik ini, kain dilipat dan diikat menggunakan tali, kemudian di celup. Kain yang tidak diikat merupakan tahapan yang paling penting, jangan sampai merusak bahan. Setelah proses ikat dan pencelupan, bahan distim dan dibentang untuk menghilangkan kerutan. Teknik ini digunakan untuk membuat motif-motif salur.

\section{HASIL DAN PEMBAHASAN}

Hasil percobaan eksplorasi pengembangan teknik Shibori pada beberapa motif tradisional Indonesia ditunjukkan pada Tabel 1. 
Eksplorasi teknik shibori dalam pengembangan desain motif tradisional Indonesia pada permukaan kain sandang (Dermawati Suantara, dkk)

Tabel 1. Pengembangan Motif Tradisional menggunakan Teknik Shibori

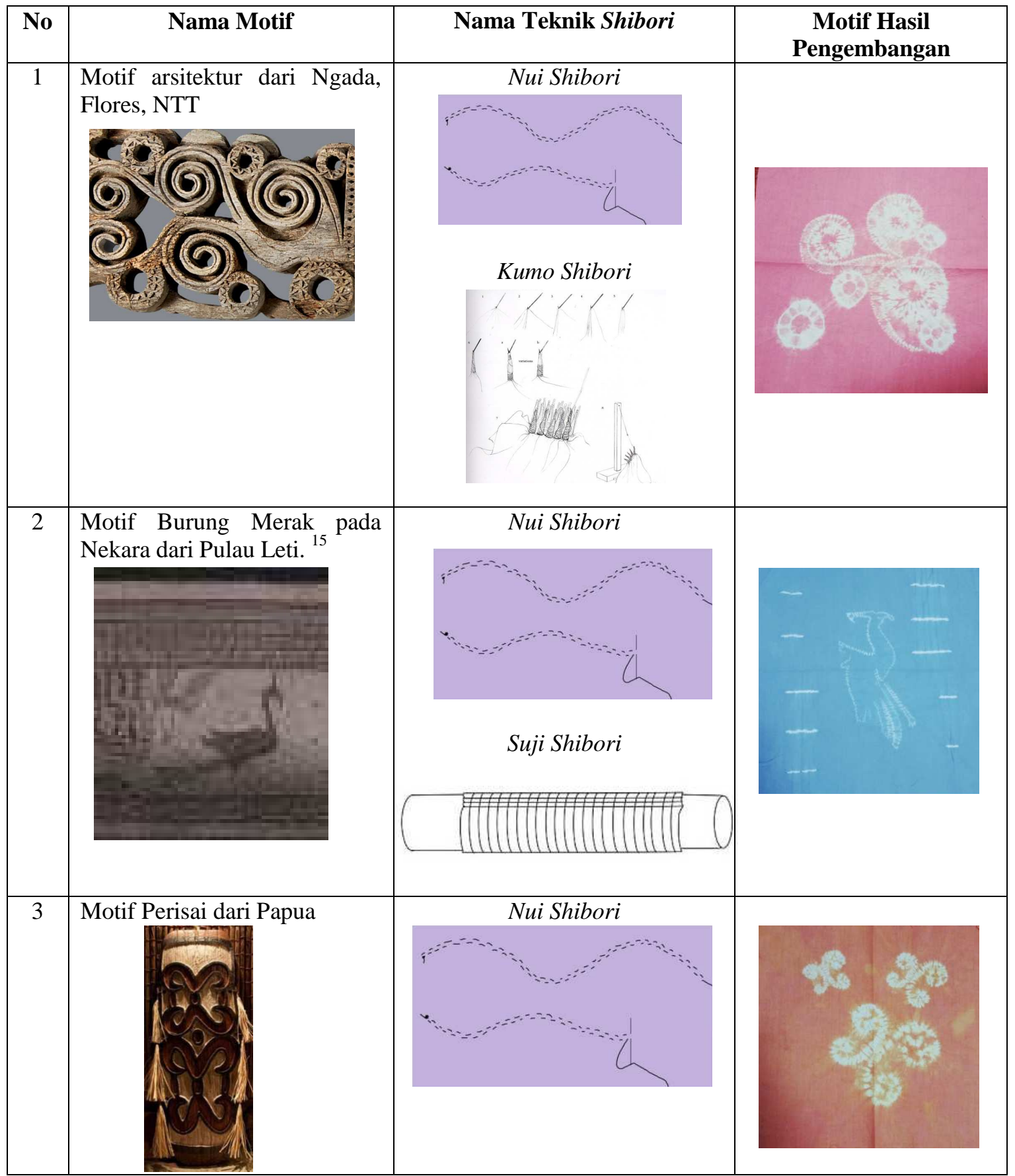

Proses pengerjaan yang menggunakan teknik Nui Shibori dengan jarak stitch (jahitan) yang rapat menghasilkan motif Shibori yang detail, terutama bagian yang terdapat lengkungan (lingkaran) membentuk motif dengan jelas. Proses pengerjaannyapun membutuhkan waktu yang cukup lama. 


\section{Pengukuran persepsi visual hasil pengembangan motif}

Pengukuran persepsi visual dilakukan untuk memperoleh informasi dari pasar mengenai kesan/persepsi yang didapat dari motif hasil pengembangan teknik shibori yang telah dilakukan.

Metode pengukuran menggunakan metode semantik diferensial. Semantik diferensial dapat digunakan untuk memperoleh informasi dari konsep/stimuli yang berbentuk verbal, namun dapat juga digunakan dalam menilai sebuah nilai estetika dalam bentuk gambar, foto, maupun benda tiga dimensi. ${ }^{16}$

Item pengukuran meliputi: (1) tingkat kemiripan motif dengan motif acuan; (2) tingkat kerumitan motif; (3) klasifikasi jenis motif; (4) tingkat keunikan motif; (5) komposisi motif; (6) kesan pembawaan motif; (7) tingkat ketertarikan; dan (8) minat membeli. Pertanyaan dibentuk dari kata-kata sifat yang berlawanan diletakkan pada masingmasing kutub (bipolar adjectives).

Meskipun menurut Osgood $^{16}$ biasanya skala pengukuran pada semantik diferensial memiliki nilai 0 sebagai jawaban netral, namun untuk meminimalisasi kecenderungan pemilihan jawaban netral maka nilai 0 ditiadakan, sehingga pada kuesioner hanya dibuat dalam skala 4, yang skor penilaiannya dapat dilihat pada Tabel 2. Pada item pengukuran klasifikasi jenis motif, skor persepsi dibuat terbalik karena kutub yang bernilai positif adalah "tradisional".

Tabel 2. Skor pengukuran persepsi

\begin{tabular}{cc}
\hline Skala & Skor Persepsi \\
\hline 1 & -2 \\
2 & -1 \\
3 & +1 \\
4 & +2 \\
\hline
\end{tabular}

\section{Prosedur Pengukuran}

Pengukuran dilakukan melalui survey online terhadap 50 responden. Kuesioner terdiri dari tiga bagian. Bagian pertama adalah pengisian data demografis responden. Pada bagian kedua responden diminta mengamati 3 (tiga) buah gambar ragam hias tradisional yang menjadi acuan peneliti dalam pengembangan motif shibori (R1,R2,R3). Selanjutnya di bagian ketiga responden diminta mengisi pertanyaan seputar pengukuran kesan/ persepsi visual responden terhadap 3 (tiga) buah motif shibori (S1, S2, S3).

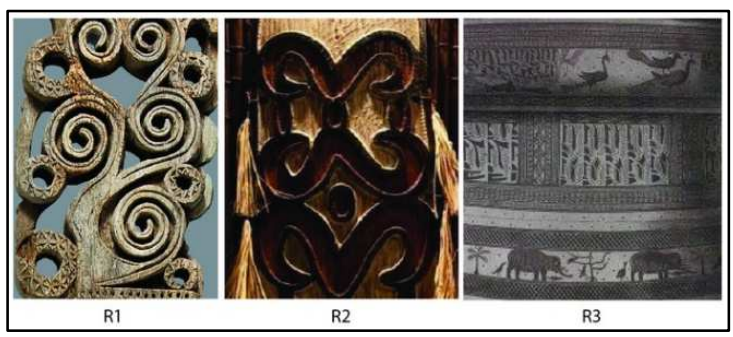

Gambar 3. Gambar Acuan Ragam Hias Tradisional

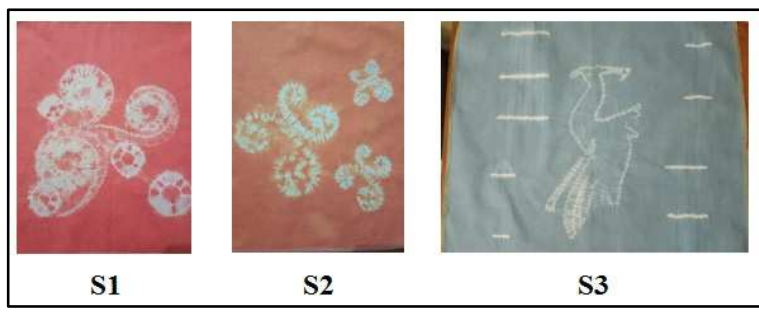

Gambar 4. Motif hasil Shibori sebagai stimuli

\section{Uji reliabilitas dan validitas}

Sebuah kuesioner dikatakan reliabel jika memiliki koefisien Cronbach's alpha minimum 0.7 (Kaplan). Sedangkan Barbara (2001) mengkategorikan koefisien realibilitas sebagai berikut: rendah $(\alpha=.26-.49)$; sedang ( $\alpha=.50-.69)$; tinggi ( $\alpha=.70-.89)$; dan sangat tinggi $(\alpha=.90-1.00)$. Dari item pertanyaan kuesioner ini didapatkan nilai alpha cronbach total adalah sebesar $\alpha=.895$ sehingga dapat disimpulkan bahwa tingkat reliabilitasnya tergolong tinggi. Sedangkan validitas telah dilakukan melalui uji distribusi normal yang dilihat dari grafik histogram masing-masing item tersebut yang menunjukkan grafik distribusi normal.

\section{Hasil Pengukuran}

Karakteristik demografis responden disajikan dalam Tabel 3. Seluruh data diproses menggunakan analisis deskriptif distribusi frekuensi dalam program SPSS versi 20, sedangkan tampilan data diolah kembali untuk kemudahan interpretasi data.

Tabel 3. Karakteristik Demografis Responden $(\mathrm{n}=50)$

\begin{tabular}{lcc}
\hline Jenis Kelamin & Frekuensi & $\begin{array}{c}\text { \% } \\
\text { Sampel }\end{array}$ \\
\hline Pria & 15 & 30 \\
Wanita & 35 & 70 \\
\hline
\end{tabular}


Eksplorasi teknik shibori dalam pengembangan desain motif tradisional Indonesia pada permukaan kain sandang (Dermawati Suantara, dkk)

Tabel 3. Karakteristik Demografis Responden $(\mathrm{n}=50)$ (lanjutan)

\begin{tabular}{|c|c|c|}
\hline Usia & Frekuensi & $\begin{array}{c}\% \\
\text { Sampel } \\
\end{array}$ \\
\hline 17- 25 (muda) & 2 & 4 \\
\hline $\begin{array}{l}26 \text { - } 34 \text { (dewasa } \\
\text { muda) }\end{array}$ & 22 & 44 \\
\hline$>35$ (dewasa) & 26 & 52 \\
\hline Pendidikan & Frekuensi & $\begin{array}{c}\% \\
\text { Sampel } \\
\end{array}$ \\
\hline SMU/SMK & 3 & 6 \\
\hline Diploma & 5 & 10 \\
\hline Sarjana & 30 & 60 \\
\hline Pascasarjana & 12 & 24 \\
\hline Pekerjaan & Frekuensi & $\begin{array}{c}\% \\
\text { Sampel } \\
\end{array}$ \\
\hline Guru/Dosen & 3 & 6 \\
\hline PNS & 14 & 28 \\
\hline Karyawan Swasta & 5 & 10 \\
\hline Karyawan Kontrak & 2 & 4 \\
\hline Freelance & 4 & 8 \\
\hline Wiraswasta & 12 & 24 \\
\hline Ibu Rumah Tangga & 3 & 6 \\
\hline Tidak bekerja & 7 & 14 \\
\hline Disiplin ilmu & Frekuensi & $\begin{array}{c}\% \\
\text { Sampel } \\
\end{array}$ \\
\hline Senirupa/desain & 13 & 26 \\
\hline Non-senirupa/desain & 37 & 74 \\
\hline Domisili & Frekuensi & $\begin{array}{c}\% \\
\text { Sampel } \\
\end{array}$ \\
\hline P.Jawa & 44 & 88 \\
\hline Luar P.Jawa & 6 & 12 \\
\hline
\end{tabular}

Dalam tahap analisis data, dilakukan perhitungan melalui penjumlahan seluruh skor persepsi kemudian menghitung rata-rata (mean) persepsi setiap item pengukuran untuk ketiga motif yang dijadikan stimuli. Hasil perhitungan rata-rata skor persepsi dari setiap item pengukuran dapat dilihat di Tabel 4.

\section{Dari analisis statistik deskriptif} ditemukan bahwa motif yang dipersepsi sebagai motif yang paling mirip dengan motif acuan adalah motif S2 (skor rata-rata $=.5$ ), sedangkan motif yang dipersepsi paling tidak mirip dengan motif acuan adalah motif S3 (skor rata-rata $=.02) .($ Gambar 5)

\section{Tingkat kemiripan motif dengan motif acuan}

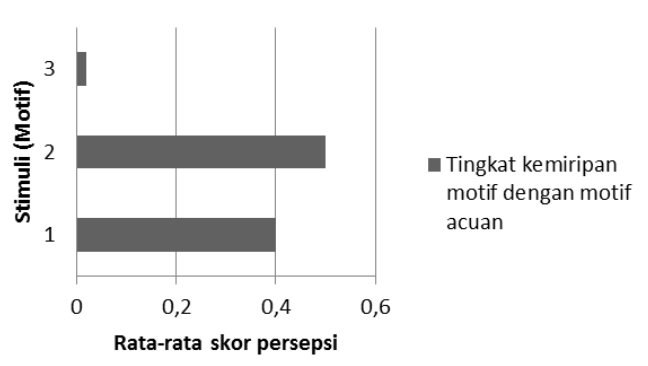

Gambar 5. Tingkat kemiripan motif

Menurut responden, motif S3 dapat diklasifikasikan sebagai motif tradisional (skor rata-rata $=.18$ ), sedangkan motif S2 dapat diklasifikasikan sebagai motif modern (skor rata-rata $=-.02) .($ Gambar 6$)$.

Tabel 4. Rata-rata skor persepsi

\begin{tabular}{lccc}
\hline \multirow{2}{*}{\multicolumn{1}{c}{ Item Pengukuran }} & \multicolumn{3}{c}{ Rata-rata Skor Persepsi } \\
\cline { 2 - 4 } & S1 & S2 & S3 \\
\hline Tingkat kemiripan motif dengan motif acuan & .4 & .5 & .02 \\
Tingkat kerumitan motif (sederhana - rumit) & .32 & -.22 & .22 \\
Klasifikasi motif (tradisional - modern) & .08 & -.02 & .18 \\
Keunikan motif (pasaran - unik) & .18 & .08 & .56 \\
Komposisi motif (monoton - dinamis) & .62 & .24 & .54 \\
Kesan pembawaan motif (norak - elegan) & .66 & .34 & .54 \\
Tingkat ketertarikan & .26 & -.1 & -.02 \\
Minat membeli & .08 & -.22 & -.16 \\
\hline
\end{tabular}




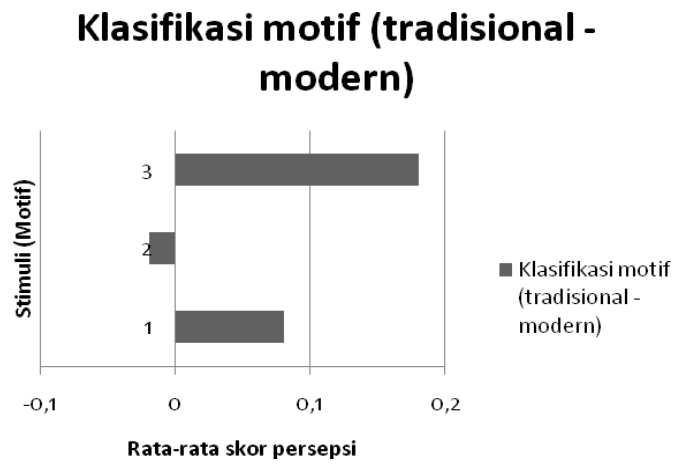

Gambar 6. Klasifikasi jenis motif

Sebuah desain motif memiliki elemen visual yang dipersepsi sebagai satu keutuhan objek dengan membawa kesan tertentu. Terdapat lima item pengukuran bipolar adjective words yang menggambarkan persepsi responden terhadap elemen visual yakni kerumitan, komposisi, dan keunikan motif. Gambar 7 menunjukkan bahwa dilihat dari tingkat kerumitannya, motif S1 dipersepsi sebagai motif rumit (skor rata-rata $=.32$ ) sedangkan motif S2 dipersepsi sebagai motif sederhana (skor rata-rata $=-.22$ ). Gambar 8 menunjukkan bahwa komposisi motif S1 dianggap dinamis (skor rata-rata $=.62$ ) dan motif S2 dianggap monoton (skor rata-rata= .24). Gambar 9 menunjukkan bahwa responden mempersepsi motif S3 sebagai motif yang unik (skor rata-rata $=.56$ ) dan motif yang dianggap umum/pasaran adalah motif S2 (skor rata-rata $=.08$ ). Sedangkan Gambar 10 menunjukkan bahwa motif S1 dinilai elegan (skor rata-rata $=.66$ ) dan motif S2 dinilai norak $($ skor rata-rata $=.34)$.

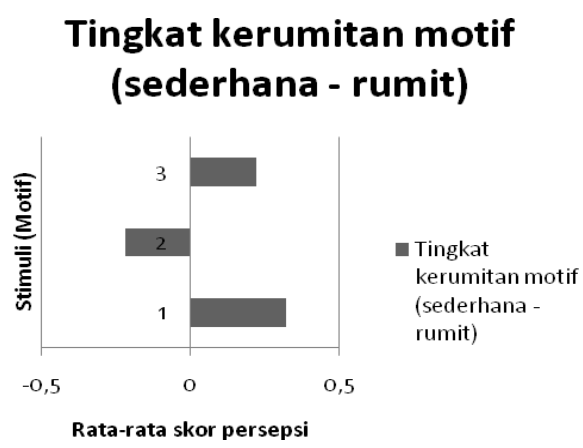

Gambar 7. Tingkat kerumitan motif

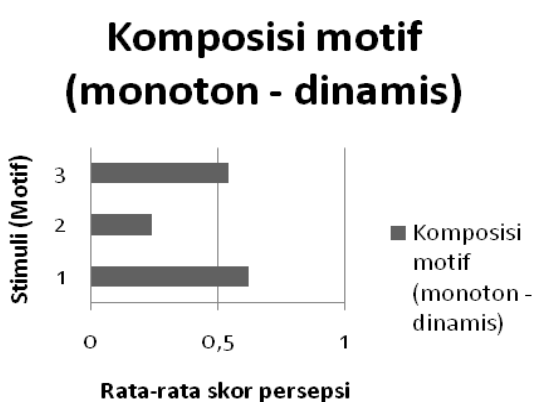

Gambar 8. Komposisi motif

\section{Keunikan motif (pasaran -} unik)

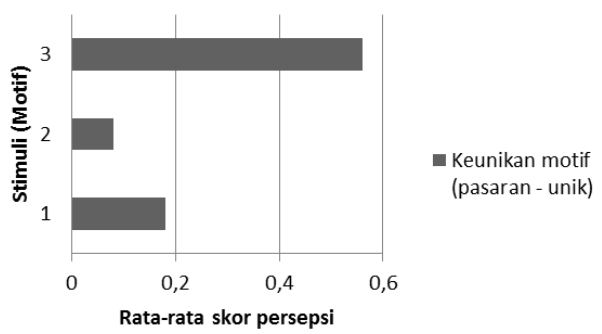

Gambar 9. Tingkat keunikan motif

\section{Kesan pembawaan motif (norak - elegan)}

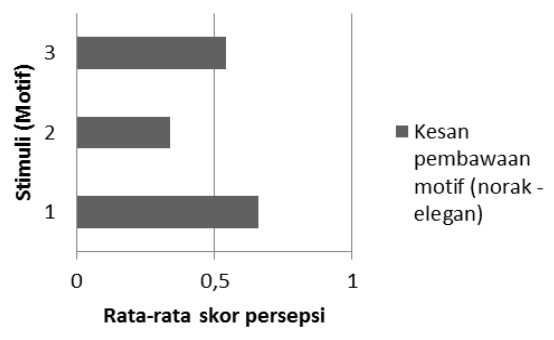

Gambar 10. Kesan pembawaan motif

Terakhir dilakukan pengukuran preferensi responden terkait tingkat ketertarikan dan minat membeli kain dengan aplikasi motif shibori yang dibuat. Diperoleh informasi bahwa motif S1 adalah motif yang paling disukai responden (skor rata-rata $=.26$ ), dan memiliki tingkat minat beli responden paling tinggi (skor rata-rata $=.08$ )

\section{KESIMPULAN}

Pengembangan motif tradisional dalam kegiatan eksplorasi ini, merupakan titik tolak untuk IKM Tekstil dan Produk Tekstil agar dapat mengembangkan desain motif tradisional menggunakan beberapa teknik Shibori, 
Eksplorasi teknik shibori dalam pengembangan desain motif tradisional Indonesia pada permukaan kain sandang (Dermawati Suantara, dkk)

sehingga dapat menjadi nilai lebih suatu produk kain yang berbasis teknik Shibori.

Kegiatan eksplorasi ini telah menghasilkan kain Shibori dengan motif tradisional khas Indonesia yang telah dikembangkan sedemikian rupa. Teknik Shibori dan pengembangan motif tradisional Indonesia ini dapat diterapkan oleh IKM celup ikat, untuk memperkaya khasanah motif tradisional Indonesia yang dapat lebih dikembangkan. Lebih jauh lagi, ditemukan bahwa motif tradisional yang terdapat pada kain, arsitektur maupun peralatan tradisional Indonesia dapat dikembangkan ke dalam motif baru yang diperuntukkan untuk kain sandang dan dibentuk menggunakan teknik Shibori.

Dari hasil pengukuran yang dilakukan menggunakan metode semantik diferensial terhadap 50 responden, dapat diperoleh informasi mengenai: (1) persepsi terhadap perbandingan tingkat kemiripan dan klasifikasi motif; (2) persepsi terhadap elemen visual; serta (3) informasi tingkat ketertarikan dan minat membeli kain dengan aplikasi motif shibori yang dibuat. Pengukuran ini dapat dilakukan oleh IKM untuk memprediksi nilai jual desain produk yang mereka buat, dengan pemilihan bipolar adjective words yang dapat dikembangkan sesuai dengan karakter komoditi produk lainnya.

\section{PUSTAKA}

1. Kartika, I., Pengembangan Desain Tekstil 3 Budaya dengan Tema Etnik Kontemporer. Dinamika Kerajinan dan Batik 27, 30 (2010).

2. Wada, Yosiko., Rice, M. K \& Barton, Jane. Shibori: The Inventive Art of Japanese Shaped Resist Dyeing. Kodansha International, (1983).

3. Wada, Y.,. What Is Shibori?. Available at: World Shibori Network.htm (Accessed: $29^{\text {th }}$ March 2017).

4. Fitinline. Sejarah Kain Jumputan di Indonesia. Available at: https://fitinline.com (Accessed: 6 ${ }^{\text {th }}$ June 2017).

5. Pujiati, S. E. Teknologi Proses Tekstil Kerajinan Tritik Jumputan. Panduan dalam Pelatihan Teknologi Tekstil Kerajinan Tritik Jumputan dengan Zat Warna Alam. (Balai Besar Kerajinan dan Batik, Yogyakarta, 2005).
6. Ristiani, S \& Nugrahani, I. Eksplorasi Pewarnaan Teknik Smock Kombinasi Tritik Jumputan untuk Produk Fashion. Dinamika Kerajinan dan Batik 31 (2), 87-88 (2014).

7. Adding Life to Cloth: The Colorful Art of Shibori. Available at: fibre2fashion.com (Accessed: $6^{\text {th }}$ June 2017).

8. Susiati, Y. T \& Kartikasari, E. Fiksator untuk Pewarna Alami. 32, (FKIPUniversitas Sarjanawiyata Tamansiswa, 2016).

9. Sinclair, R. Textile and Fashion: Materials, Design and Technology. (Woodhead Publishing Series In Textiles, 2014).

10. Murwati, E. S., \& Ristiani, S. Inovasi Motif Jumputan. Prosiding Seminar Nasional $4^{\text {th }}$ UNS SME's Summit \& Awards, 23 (2015)

11. Titisari, B., Kahdar, K \& Mutiaz, I. R. Pengembangan Teknik Jahit Celup (Tritik) dengan Pola Geometris. ITB J. Visual, Art \& Design 6 (2), 131 (2014).

12. Putra, E.S., Perancangan Diversifikasi Produk Tenun Tajung Khas Desa Tuang Kentang Kota Palembang Propinsi Sumatera Selatan. Laporan Penelitian. Lembaga Penelitian dan Pemberdayaan Masyarakat. Institut Teknologi Nasional. 8 (2011).

13. Southan, M. Shibori Design and Techniques. Tunbridge Wells, Kent, UK: Search Press, (2009).

14. Sancaya, R., Sugiarti \& Riswati, M. K. The Enchanted Nature Colors of Indonesia. Kehati, Jakarta, (2011).

15. Sunaryo, A., Ornamen Nusantara: Kajian Khusus tentang Ornamen Indonesia. Dahara Prize, Semarang, (2009).

16. Osgood, C.E., Suci, G.J. \& Tannenbaum, P.H. The Measurement of Meaning. University of Illinois Press, USA, (1957). 
Arena Tekstil Vol. 32 No. 2, 2017: 67-76 